\title{
A critical study of Acts 6:1-3 and its implications for political restructuring in Nigeria
}

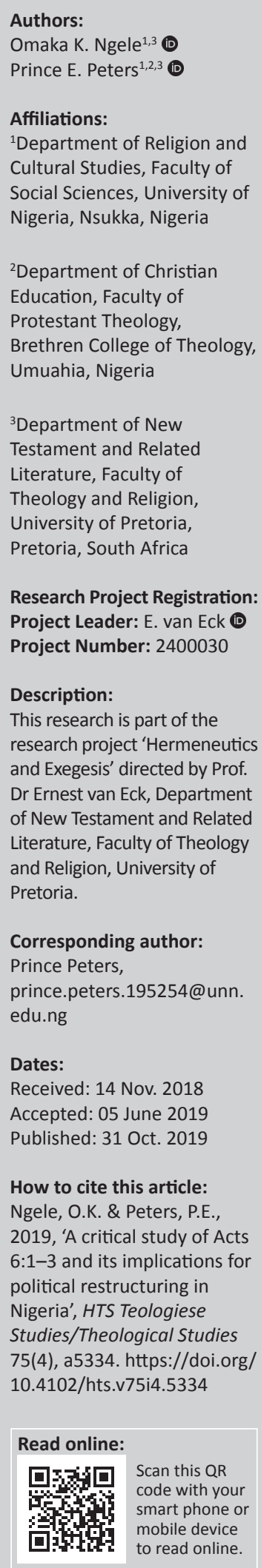

Corresponding author:

Prince Peters,

prince.peters.195254@unn.

edu.ng

Dates:

Received: 14 Nov. 2018

Accepted: 05 June 2019

Published: 31 Oct. 2019

How to cite this article: Ngele, O.K. \& Peters, P.E., 2019, 'A critical study of Acts 6:1-3 and its implications for political restructuring in Nigeria', HTS Teologiese Studies/Theological Studies 75(4), a5334. https://doi.org/ $10.4102 /$ hts.v75i4.5334

\section{Read online:}

Scan this QR
code with your
smart phone or
mobile device
to read online.

The nascent church in Jerusalem represented in Acts 6 verses 1-3 was promptly challenged by the problem of inequity and lack of fair play among the various stakeholders and such disaffection reached a situation of murmur and open agitation. This challenge to the apostles was a threat to the consolidation of the already established Christian community in Jerusalem and its spread to the whole world. Something must be done to arrest the situation or the Church runs the risk of disintegration. Having some moral lessons drawn from the pericope at the back of the mind, one notices that recently there has been a clamour by the different geopolitical groups in Nigeria to restructure the Nigerian political system. The clamour is based on the failed position of post-war federalism to give all parts of Nigeria's pluralistic society a fair and equal representation which hitherto was meant to stop Nigeria from another civil war or the cry for cessation by one region or another. The church, as an impartial umpire in the art of politics, should, in the midst of the turmoil, serve as the conscience of the masses, pressing hard to the actualisation of the demands of the masses. The study, through historical-critical method of biblical scholarship with Form criticism, analysed that situation of agitation to inequality and gross misrepresentation in the book of Acts 6:1-3, pressing to offer vital lessons to Nigeria in her quest for political restructuring. It concluded by finding out that Nigeria's pluralistic nature, when restructured, should be a catalyst for global vision attainment and sustainable development.

Keywords: Theology; Politics; Restructure; Church; Nigeria; Federalism.

\section{Introduction}

At the inception of Christianity in Jerusalem, as documented by Luke in Acts of the Apostles, the church took off on a very healthy ground with the incorporation of Hebraic and Hellenistic Jews as the major components of the nascent church. But it appears that the Jews assume religious and cultural superiority over others, a factor that seemed displayed even to the Hellenistic Jews, though they were 'Jews'.

'Hellenistic' Jews were Jews born in Diaspora and who returned to Jerusalem for one reason or the other.

Slick (2018:7) believes that they 'probably interpreted the Torah less stringently than did the "Hebrews"' and this could be the brain behind the superiority complex the Hebraic Jews displayed against them. But Dunn (2009:246) argued that while earlier scholarship assumed that there must have been a theological difference between Hellenists and Hebrews, the linguistic, and therefore basically cultural, basis of the comparison has been so widely accepted that today 'the point is not in dispute'. So this study aptly agrees with Dunn that culture (which of course includes language), not theology, was the brain behind the neglect and inequity meted out to the Hellenistic Jews by the Hebraic Jews. This character produced an unequal treatment of the estranged Jews of Greek origin to the extent where the humanitarian service of the church to the indigent widows was mainly concentrated on the Hebraic or Jerusalem Jews and not equitably distributed also to the Hellenistic Jews. Such a foul play in the young church brought the challenge of murmuring, which led the apostles to seek to restructure the already structured social gospel, which, before now as earlier said, favoured only an aspect of the church populace. The same situation broadly applies in the Nigerian context today. Sadly but true, it is evident that the Nigerian federal system of government which was meant to be the machinery, which would carry everyone along, failed. By definition, federalism is said to be (Joseph 2014):

[A] form of political organisation that is most suitable for plurinational states because of its potential to foster unity in diversity and peaceful co-existence among the diverse and territorially concentrated groups in a state. (p. ii)

Copyright: (C) 2019. The Authors. Licensee: AOSIS. This work is licensed under the Creative Commons Attribution License.

Note: Paper presented at the 29th annual conference of PEAN held at Lagos State University, cited in Ayeni, M.A. \& Adeleye J.O., 2013, 'Education and Political Restructure in Nigeria', Journal of Education and Learning 2(1), 171-175. 
There are evidences that federalism has worked in other multifaceted nations as a centripetal force to effectively curb the centrifugal force that should naturally keep the various nationalities that form the federation divided, but sadly federalism has refused to effectively work in Nigeria to this purpose owing to what Joseph called 'dearth of peace enabling federative culture in Nigeria' (2014: ii).

The collapse of federalism in Nigeria's pluralistic state and its consequence of championing ethnic interests based on high cultural differences therefore necessitated the agitation for restructuring in the Nigerian state.

\section{Theology}

Unlike religion, theology has a narrow definition consequent on its reserved and unmitigated use. Karlson (2009) defines theology from two perspectives. He said (Karlson 2009):

[T]hat the first could be described as 'God-talk': It is logos (speech) with theos (God). In this way, prayer is seen as theology proper. In time, this led to a second definition - that theology involves the study of God. The early Christians, after all, were facing new questions both from fellow Christians confused about Church doctrine and from non-Christians who challenged believers to credibly explain their faith. Origen, in many respects, is considered the founder of this kind of theology (though we can find precedents from St. Clement of Alexandria and the apologists before him). This, then, became speech (logos) about God (theos). (p. 1)

This study considers Karlson's two-point definitions to represent the conceptual and operational positions of the term, respectively, and so becomes all inclusive.

\section{Politics}

Oguntola-Laguda (2008:124) and Ngbea (2012:104) define politics as the acquisition of power and the use of such power'. Curran (in Ngbea 2012:103-104) approaches the subject from an etymological perspective when he explains that it 'came out of two Greek words polis which means "city" and teche which means an art, a skill or a method that is, the art of governing a city'. Onyekpe (in Dukor 1998:16) sees politics as 'the struggle for power which itself is the authority to determine or formulate and execute decisions and policies which must be accepted by the society'. While Pennock and Smith (1964) view politics as:

[T]hat which has to do with the forces, institutions and organisational reforms in any society, that are recognised as having the most inclusive and final authority existing in that society for the establishment and maintenance of order, the effectuation of other conjoint purposes of its members and reconciliation of their differences. (p. 9)

Although these definitions are academically up to date, the study believes that politics is a tool necessary to pilot the affairs of any organisation or society and by doing so defines it as the effort to possess the required mandate to rule and/or make laws. This definition places the efforts of the apostles in Acts 6:1-3 as wholly political.

\section{Restructure}

The concept of restructuring has become a bit complex in explanation, with lots of things said about it yet at the same time, having been scarcely defined from the time it entered into the Nigerian vocabulary. However, Bello (2017) defined it as:

[T]he process of increasing or decreasing the number of component parts that makes up a system and re-defining the inter-relationship between them in such a way that the entire system performs more efficiently. (p. 10)

He discovered the various modes of restructuring, which he listed as 'Wholesale restructuring or Piecemeal restructuring; Fast-paced restructuring or Gradual restructuring; Shortterm restructuring or Long-term restructuring; Governmentdriven or people-driven restructuring; and Formal or informal restructuring'. Bello (2017:12) opined that 'the outcome of any restructuring will depend to a great extent on which of the above modes of restructuring is adopted by Nigeria', and he insists that most heads of state or governments in the past have made restructuring most times, unwittingly in the Nigerian polity.

Bello's definition characteristically subjects the process of restructuring to a mechanical function without aligning it to the activities of human beings in a given society, say Nigeria. It is on this note that the research comes in to opine that restructure should be seen with the lenses of reshuffling of an already working system for optimum performance and result.

\section{Church}

Mueller (1934:541) defines the church as the communion of believing saints which the Holy Ghost thus gathers through the gospel'. The striking feature of Mueller's definition is the mention of the operation of the Holy Spirit through the agency of the gospel, and not limiting the definition of the church to one creedal statement or another, a fact that most modern definitions ignore. Berkhof (2003) conceptually affirms that:

[T] he New Testament ... has two words derived from the Septuagint, namely ekklesia, from $e k$ and kaleo, 'to call out', and sunagoge, from sun and ago, meaning 'to come or to bring together'. The latter is used exclusively to denote either the religious gatherings of the Jews or the buildings in which they assembled for public worship. (p. 555)

Berkhof (2003:555-556) further stated that 'the term ekklesia, however, generally designates the church of the New Testament ${ }^{\prime}{ }^{1}$

\section{The historical reconstruction of Acts 6:1-3}

The book of Acts of the Apostles is the only book that serves as a bridge between the four gospels and Paul's epistles (Parsons

1.Even though Ekklesia is a general word designating 'what is called out or forth' (see Young's Concordance to the Bible, p. 59), Bullinger claims that the word was (see Young's Concordance to the Bible, p. 59), Bullinger claims that the word was (signally used 'of any assembly, but especially of citizens, or of a selection of them ...' (see Bullinger 1898). Figures of Speech used in the BIble (p. 72) and not the Christian assembly per se. The Christians later adopted it to designate their religious movement and its places of worship after Paul used it in that context in his writings (e.g. Col 1:18). 
2015:19) and by extension the early church. Its historicity elicits in itself the clarity of God's desire to demystify his Person, capturing the gospel tradition in a historical genre. Chambers (2012:10) argues that 'asking questions of a historical nature about things like authorship, date, occasion, genre, and purpose affirms that God's self-disclosure did not occur in a historical vacuum'.

This is so when one considers that Luke in Acts presents the movement of the church and the operations of the Holy Spirit in tandem with verifiable geographical and cultural landmark. The study may not consider Luke as a historian from the modern perspective of history because 'Luke does not display a historian's intellectual autonomy' and that 'his reading of history is a believer's reading' (Marguerat 2002:21), yet his history is just enough to state the operations of the Holy Spirit and the mistakes of the budding church. In regard to authorship, people like Adolph Harnack do not in the least blink in attributing it to Luke, for he referred to the book of Acts as 'his (Luke's) "Acts of the apostles"' (1909:xiii). The history behind the pericope under study was that of political marginalisation against the Jews by the Romans, which led to economic impoverishment especially within the 1st-century Palestine of which its effect spilled into the Jerusalem church and Kinoshita (2015:76), capturing the situation in its totality made reference to the work of Kraybill, who informed that in 63 BCE, Roman General Pompey conquered Jerusalem and from that time Israel again experienced domination from an imperial power (Kraybill 2003:48). After the death of Herod the Great, Israel was divided into three major sections and was ruled by different leaders. Kraybill (2003) summarised:

Thus as Jesus began his ministry about 25 C.E., Palestine was a churning cauldron of revolution. Philip, Herod the Great's son, ruled the northeast region as a quasi-Jewish king. Herod Antipas, another son, ruled the Galilee area in similar fashion ... a Roman ruler (procurator), from the seacoast port of Caesarea, directed the Judean affairs including Jerusalem, in the southern region. (p. 48)

Linthicum (2005:34) asserted that the Jewish religious system was also a governing system along with the Roman government and worked alongside the Roman procurator in Judea and with the Herodian nobility in Galilee. This may give some insights as to the tension that occurred regularly between Jesus and the religious leaders of his day. Linthicum (2005:34) also commented on the socio-economic situation of Palestine during this time. The religious leaders, Herodian nobility and landowners consisted of only $2 \%$ of the population yet controlled up to $70 \%$ of the region's wealth, often leading to tension and unrest throughout the land.

Linthicum (2005:34) emphasised the larger per cent of people were peasants who 'perennially lived on the edge of economic disaster', stating further that after subtracting taxes paid to the government, Jewish authorities and the landowners, a typical farmer realised 'only about 12 per cent of his harvest as his family's annual income and the monies to purchase next year's seed' (Linthicum 2005:35). Kinoshita (2015:77) believed that many biblical narratives involve peasants who interacted with Jesus and were among his closest followers. He, however, stated that Linthicum (2005:34) introduced another social class referred to as the 'expendables' that were a major focus of Jesus, commenting: every peasant family lived in fear that one day they would slip over the edge into economic disaster and become one of the 'expendables'. According to him, the expendables of Israelite society included the beggars, the excess children of peasant farmers, the widows and orphans, the unclean and the shepherds (Linthicum 2005:34).

Linthicum (2005:35) explained, '[ $m]$ ost of the people Jesus healed were expendables'. Under the dominance of Rome, the vast majority of people lived in strained socio-economic conditions; they were either peasants or expendables. Kinoshita (2015:77) therefore boldly said, 'the poverty in the land of Israel paints a sobering reality that is a significant factor for Israel and its economic instability'. Lastly, according to Kinoshita, DeYoung et al. (2003) seriously bemoaned the issue of inequality in time when Jesus lived in Galilee:

The world in which Jesus and members of the church lived did have distinction that brought division and hierarchies that produced discrimination rooted in personal and societal understandings of ethnicity and culture. These differentiations often contained the same emotional and structural power to divide as race does today. This was particularly true of the divide between Jews and Gentiles (people from other nations). Biblical scholar Joachim Jeremias notes that the attitude of many Jews toward Gentiles in Jesus' time 'was largely determined by the oppression which they had undergone at the hands of foreign nations, and by their fear of the increasing prevalence of mixed marriages'. (p. 11)

Such cultural marginalisation and harsh political treatment meted out on the Jews of Jesus' time, especially by the Romans, were inadvertently the brain behind the Jewish racist mindset which even affected the way they handled their fellow Jews of Greek extraction. Arnold (n.d.) explains that:

[I]n the Church at Jerusalem there were Palestinian Jews who were born and bred in Israel and who spoke Hebrew and Aramaic, and there were Hellenistic Jews who were Jews born and bred in the Greek and Roman lands outside of Palestine. Even before the Christian church came on the scene of history, the Palestinian and Hellenistic Jews always had conflicts because of cultural differences which led to distrust and bickering between these groups. When the gospel was preached to Palestinian and Hellenistic Jews, some of both groups responded to Christ and were saved. However, salvation did not wipe away all cultural differences, and they carried many of the same distrusts into their Christian lives. (para. 6)

Consequently, their reaction to the Hellenists in the church was a step too far as a reactionary measure to what the Romans meted out on them in the past.

\section{Political restructuring and the apostolic challenge in Acts 6:1-3 Textual analysis}

\section{Verse 1 increment in population by the church}

The first apostolic challenge to organised leadership and politics started with an increase in the number of souls won into Christianity. Usually, growth in population in any 
organised state or entity seems to be one of the disturbing factors to proper management and equitable distribution of resources especially when such growth in the entity comes with cultural diversity. It can be baffling when one imagines the total number of persons in the young church as of the time of the event that led to the study if about 3000 people joined the church only in 1 day (2:41). No wonder the Greek word that was used to describe the multiplication was a neuter noun $\pi \lambda \tilde{\eta} \theta 0 \varsigma$, which primarily means 'a multitude'. In fact, Strauch (n.d.:5) opines that 'by the time of the events of Acts 6, there were approximately five thousand to ten thousand (possibly more) new believers in Jerusalem' and these people were not departmentalised because there were no sects, denominations or branches at that time. Imagine what the crowd under the apostles would be like in a religion which, within the first five centuries, 'became the dominant religion of the Roman Empire' (Tolan 2015:166). With such growth in population, but with poor political structure, the church (like the community of slaves under Spartacus within the Roman Empire) was entering into the phase of radical but non-violent revolt by these Christians. Really one does not expect the soul salvation of those who flock into the church to eradicate their human needs of freedom and equal treatment; this is especially applicable to the Hellenists who, as it were from their composure in the passage, looked more enlightened than their Hebraic brethren (Douglas 1971:21). Consequently, there was murmur. The study is not very sure what the main treatment meted out on the Hellenists' widows was because scholars do not agree on the best interpretation of the phrase that is assumed to have caused the problem 'the daily distribution' (Strauch n.d.:5) in this verse; however, the etymology of the word translated

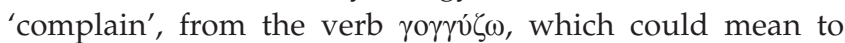
'murmur', 'mutter', 'grumble', 'say anything in a low tone', creates an understanding that whatever the case was, it was sequel to a series of neglect that turned into a habit of gross abandonment. Again, from the preposition $\pi \alpha \rho \alpha$ [beside] and the verb $\theta \varepsilon \omega \rho \varepsilon \dot{\varepsilon} \omega$ [which the study would call 'I partake of'], the verb $\pi \alpha \rho \varepsilon \theta \varepsilon \omega \rho$ ovv $\tau^{\prime}$ in the imperfect indicative middle or passive third person plural emerges and translates 'were being overlooked'. The verb concretises the assertion made in this study that the aggrieved party (the Hellenists) were truly marginalised in the structure of the church as of that time.

\section{Verses 2-3 The summons and overhaul of the entire church polity}

According to Expositor's Greek Testament:

[W] hatever may have been the irritation caused by the pride or neglect of the Hebrews, the Apostles recognised that there was ground for complaint, and thus showed not only their practical capacities, but also their freedom from any partiality. (https:// biblehub.com/commentaries/egt/acts/6-2.htm)

The main argument here is that the 12 apostles took a bold step to balance power between the Hebraic and the Hellenistic Jews, by restructuring the already structured church polity that placed only the Hebraic Jews at the helm of affairs at the expense of their Hellenistic brothers, and planting seven men to take care of the welfare of the populace and so it is timely to assert that 'the early Church was not afraid to do two things that are always difficult: share the power and make structural changes' (Thurston n.d.:6). However, to restructure the church government, the apostles summoned not only the 120 people who earlier gathered at the upper room, but the entire disciples, which would in fact include everyone to deliberate on this all important decision. This makes it clear that good leadership must be all encompassing, which is the hallmark of pure democracy.

\section{Ellicott (1897) makes it clear that:}

The collective action of the multitude is strikingly in harmony with the Greek ideas attached to the word Ecclesia, as the assembly in which every citizen might take his share. Representative government might come as a necessity of later times; as yet, every member of the congregation, every citizen of the new polity, was invited, as having a right to vote. (https:// biblehub.com/commentaries/Ellicott/acts/6-2.htm)

In the circumstance, the church demonstrated its unwillingness to victimise or even display any form of partiality based on any shared sentiment at all.

\section{Exegetical summary}

The study's exegesis came out with the result that there was actually a political problem of poor structure that affected the overall welfare of the Christian populace within the earliest Christianity and that would have been a problem to the growth of the organisation if it was not well managed. This is just an aspect of the negative leadership styles exhibited by the leadership of the Jerusalem church. The study found out that the problem (which was disaffection in some quarters by some unsatisfied group of persons) was, however, resolved by the sheer determination of the apostles to restructure the government of the day to also include Hellenists. This submission was drawn from the understanding that the seven deacons elected to serve table were Hellenistic Jews. Douglas (1971:22) was of the opinion that the deacons 'must have been the leaders of the new Hellenistic Christian church, and not of the original Jerusalem church'. This opinion marks the distinction between the Hebraic Christians and the Hellenistic Christians. Whatever started such agitation is subject to debate; however, the apostolic team, which was the highest decision-making body at the time, had to tackle it head on. The pericope had a textual problem wherein $\delta \dot{\varepsilon}$ (therefore) was preferred by $\aleph$ B it ${ }^{*}$ cop $^{\text {samss }}$ and oũv (accordingly) was preferred by C E $\psi$ including numerous minuscles. The study, however, followed the former variant owing to sufficient internal and external supports it amassed.

\section{Political restructure in Nigeria: A hermeneutics of Acts 6:1-3}

Call for restructuring the Nigerian polity has become highly tuned up presently on the singular basis that the "nation has had a chequered history in terms of political development since she attained political independence half a century ago' 
(Ayeni \& Adeleye 2013:171). Arguably, whether it is a secular or a religious institution, an organised sector comprising people, especially those with cultural divergences, would be susceptible to unfair treatments which invariably leads to complains, and Nigerian populace naturally displays same reaction like the Hellenistic Jews in Acts 6:1-3. Nwafor (2011) believes that Nigeria should not be a paper-tiger giant of Africa, but an economic, political, stable, dynamic and development-driven nation. Contrary to expectations, and quite correctly, he thinks that her experiences so far have been quite traumatic, excruciating and challenging; and riddled with coups d'état and counter coups, a civil war, annulment of the freest and fairest elections, social and economic strangulating policies and bad leadership, endemic corruption and grinding poverty, acute unemployment, religious intolerance, hostage taking, militancy and terrorist attacks on innocent citizens. He concludes that the litany of the prevailing social malaise is interminable. Again, since:

[T]he basic minimal structures required for a country to lay claims to the practice of federalism include a political system in which there is power sharing under a written constitution with a government consisting of at least two orders: a central or federal government and the governments of the constituent units [with] each order of government receiv $[i n g]$ an allocation of financial resources tailored to their specific requirements. (Obidimma \& Obidimma 2015:147)

Nigeria could easily pride herself as operating federalism subsequently, but Obidimma and Obidimma argue that this basic requirement of federalism has not been attained in the Nigerian federalism since 1954 that Nigeria has been a federal state. Therefore, because the idea of true federalism that propelled the nation's heroes past (from North and South) to greater heights collapsed, 'crass opportunism and enlightened self interest have given birth to small minds as 'Big Men' who have led the country to the nadir of reproach' (The Guardian 2016:9). In what seems like a summary of the Nigerian impediment, Omotola (2010:135), Atofarati (1992:3) and Ayeni and Adeleye (2013:172) traced Nigeria's problem to the unfortunate developments of the 1960s. They were of the opinion that the issue of ethnic politics started with the 1964 elections in Nigeria when Nnamdi Azikwe, an Igbo man through his party NCNC's alliance with another party, UPGA, won the election into Western Nigeria's house as Premier, but was denied of occupying the position because he was not a Yoruba man (Omotola 2010:135). The subsequent developments led to a series of crisis which eventually ushered in the first military coup and counter-coup of 1967 (Atofarati 1992:2). The report (Ayeni \& Adeleye 2013) further stated that:

... [E]thnic consciousness heightened with the death of Major General Aguiyi Ironsi. The military administration of Gowon rode into limelight through an appeal to national sentiment that saw the Northern elements leading the nation, with the claim that they were championing the corporate interest of Nigeria. The North was favoured in everything, including developmental projects, giving room for Kano State to have 44 local governments while Lagos State has 20 even though the two states have nearly the same population. Some of these awkward practices (the killing of Ken SaroWiwa and the eight Ogoni activists) later fuelled the spate of ethnic groupings in Nigeria, leading to the emergence of such groups as Odua People's Congress, Igbo Youth Council, Arewa People's Congress, Bakassi Boys, Movement for the Emancipation of Niger Delta and others. (p. 172)

It is very clear here that the Nigerian state blatantly refused to accept and, in fact, maximise its diversity in cultural and ethnic situations, which is the basis for the clamour for restructuring. Although the event in Acts 6:1-3 is employed in this study not as a political model per se (owing to the various political and cultural differences that obtains between the Jerusalem church and the Nigerian nation) but as moral and allegorical examples for Nigeria (because the Bible contains spiritual principles that can be applied in all cultures of the world), such lessons should be imbibed as fast as possible to save the Nigerian nation by restructuring or an imminent tearing along religious and ethnic lines becomes unavoidable.

Historically, Nigeria is a multi-ethnic, multi-cultural, multireligious and multi-lingual state with a population of well over 170 million people and evidence of further population explosion so; naturally, there would be the crisis of partiality and flagrant nepotism, as was the case between the Hebraic and the Hellenistic Jews in Acts 6:1-3. But apart from overpopulation, Nigeria's major problem has been its pluralism. Ngele (2008:184) argues that ethno-religious plurality has not been for the best interests of Nigeria as it has been the basis for many conflicts. Agreeably, the state is a fusion of people from different religious and ethnic backgrounds, and therefore the squabble for rights and privileges is expected. Again, having seen that federalism is arguably a conflict-solving mechanism (Gagnon 1993:15), which was the expected solution to Nigeria's pluralism and which sadly failed Nigeria, the only obvious option to solving Nigeria's cold war and marginalisation would be a restructuring of Nigeria's political and, by extension, the economic and social systems of the state. One would not forget that the study presented the apostles in Acts 6:1-3 as having gathered the populace and engaged in a restructuring effort by organising what looked like a constitutional conference that was both free and fair. Although the church understood God as the owner of the church, but the study's investigation points to the fact that the apostles were the human governors and administrators of the church and therefore needed to make critical decisions without directly consulting God, and this leaves the lesson that a political entity like Nigeria should go beyond religious sentiments and let its political leaders make critical decisions of restructuring, without necessarily consulting God or the gods.

Here, however, the distinguished economist and former Governor of Central bank of Nigeria, Prof. Chuma Soludo, in a paper published on the Cable News (2018), agrees that restructuring would be a ready solution to Nigeria's chaotic situation. He therefore stated that:

In terms of content and nature, we can group the various restructuring models into three categories: soft restructuring (tinkering with amendments of the 1999 Constitution); hybrid 
restructuring (negotiate a new Constitution with sufficient regional autonomy within the federation); and hard restructuring (confederation or outright independence for any desiring part of the country). (Soludo 2018:2)

Going by Prof. Soludo's solution to the Nigerian crisis of failed federalism, restructuring would be the only way out, but 'what should qualify for inclusion in the restructuring agenda has been a weighty obstacle to launching the process' (Abutudu 2010:24). This is why it is very difficult to choose out of the very beautiful categories Soludo has grouped restructuring.

\section{Considering the three restructuring models} Soft restructuring

This mode of restructuring is well situated in the realms of amending the twice-amended 1999 Constitution of Nigeria put together by the military, which restored democratic rule to Nigeria. But there seem to be great challenges in doing so. In a newspaper article entitled 'Nigeria won't progress with 1999 Constitution, says Bisi Akande', Makinde and Dada (2017) report the former Interim National Chairman of the All Progressives Congress, Chief BisiAkande, as saying:

The 1999 Constitution is Nigeria's greatest misadventure since Lord Lugard's amalgamation of the Southern and Northern Protectorates in 1914. The constitution puts emphasis on spending rather than making money, thereby intensifying the battles for supremacy between the legislature and the executive while the judiciary is being corruptly tainted and discredited. (Makande \& Dada 2017:9)

In the same vein, a Constitutional lawyer and professor of law, Itse Sagay, who also doubles as the Chairman of the Presidential Advisory Committee Against Corruption (PACAC), made a comparison between the 1963 and 1999 constitutions and submitted that the latter was mistakenly drafted and foisted on Nigeria (Akinrefon 2017). In his words (Akinrefon 2017):
The 1999 Constitution turns a blind eye to these major social and ethnic divergence in Nigeria forgetting that all the various states and ethnic groups were independent when the British came. This is what the 1999 Constitution has overlooked and that is why there is so much tension in the land because the federal government is regarded to be too powerful therefore putting us together in a sort of tight embrace. The various states and regions want more autonomy and freedom to operate in their own way, whilst operating in the centre to form a united Nigeria. (p. 8)

What could have angered Prof. Sagay would be some comments probably of vulgar nature, which arrogates excess power of domination to the federal government like the clause found in Chapter 1, section 2, sub-section 1, which states that 'Nigeria is one indivisible and indissoluble sovereign state to be known by the name of the Federal Republic of Nigeria'. In section 16, sub-section 2 (b), it is stated that 'the State shall direct its policy towards ensuring: that the material resources of the nation are harnessed and distributed as best as possible to serve the common good'. This could be interpreted to mean that the wealth from the South could be harnessed and distributed within federating states of the country (based primarily on their population) without any consideration to the states from which these resources come from. In chapter 1, part 2, section 10 of the 1999 Constitution, it is stated that the Government of the Federation or of a State shall not adopt any religion as State Religion'. But at the same time in chapter 7 , section 260 , subsection 1, the constitution totally forgot the kind of emotion religious ideas provoke in a pluralistic state like Nigeria and added that 'there shall be a Sharia Court of Appeal of the Federal Capital Territory, Abuja'. And in 275, sub-section 1, 'There shall be for any State that requires it a Sharia Court of Appeal for that State'. These testimonies naturally make the amendment of the 1999 Constitution problematic as a means to effective political restructuring.

\section{Hybrid restructuring}

Soludo (2018:2) continues to state that there seems to be a preponderance of mainstream opinion around the hybrid option, and the loudest case for restructuring is so far based on political and ethno-religious agitation'. The undisputed truth about the situation is that Nigerians take seriously their ethnic nationality and their religious affinity. Their allegiance, first, lies with their ethnic groups before the state (Fan, Jerry \& Nnaraonye 2014:22), and that is because nearly all Nigerians believe that Nigeria is a colonial master's (Lugard) contraption (Chinweizu 2006:1). Therefore, to keep Nigeria one and fully functional, a new constitution must be designed in which the ethnic and religious diversity must be recognised and fully respected; this is why people (especially from Southern Nigeria) prefer the 1922 Constitution, which abolished the Nigerian council (which was non-elective and ineffective) and allowed more representation of Nigerians than there were in the Nigerian council. In Acts 6:1-3, the apostles, who were all Hebraic Jews, gave the power to regulate the daily ministering to the needy in their midst to Hellenistic Jews. They never added a single Jerusalem Jew in the list of the deacons, thereby creating a balanced power. That was a restructuring process rightly gotten. The study could suggest that the different ethnic groups in Nigeria, which is loosely carved into the present six geopolitical zones, must be made to be autonomous. Such autonomy means that they should be greatly empowered - that is, they should become powerful enough to manage their own resources and ethnic sentiment, while the central government (in its three arms) becomes less powerful and attractive. This opinion is centred on the recognition of Nigeria's everpresent geographical and cultural differences which ostentatiously stare the country in the face daily.

\section{Hard restructuring}

This mode demands a confederation or outright independence to any of the federating units that seek freedom. It calls to mind the agitation for the creation of the sovereign state of Biafra out of the existing Nigeria. A method of referendum is 
intended to be used, but the end product is actually to restructure Nigeria in the hardest of ways.

\section{Recommendation and conclusion}

The study has analysed the Nigerian state as a colossal state with equally sizable problems just like the Jerusalem church presented in Acts 6:1-3 had an increasing problem when its number increased. It found that the challenge that Nigeria has, which has led to constant call for restructuring which is similar to the murmur of the Hellenistic Jews of that time, is cultural (religious and ethnic). So to solve it, a constitution that recognised the uniqueness of the various religious and ethnic nationalities in Nigeria must be drafted as urgently as possible, which shall be used as a ready tool for Nigeria's political restructuring. In such restructuring, if any of the three studied modes must be applied, then the 'hybrid' restructuring is recommended because the ethnic and religious diversity must be recognised and fully respected by it; and as earlier said, it is why people prefer the 1922 Constitution. The different ethnic groups in Nigeria, which is loosely carved into the present six geopolitical zones, must be made to be autonomous, and the hybrid restructuring provides the framework for such autonomy. Such autonomy means that they should be greatly empowered - that is, they should become powerful enough to manage both their resources and ethnic sentiments, while the central government becomes less powerful and attractive. This step reminds one of the moves made in Acts 6:1-3 by the apostles to restructure an already structured polity. This, when done, will reduce the tension at the Federal level that is caused by the scramble for political power to manipulate the state's natural and mineral resources. This will enable Nigeria to return to the zenith of her glory as an egalitarian nation just as in the case of 1963 agro-economic-driven Nigeria, where US\$65 was exchanged for one Nigerian pound.

\section{Acknowledgements Competing interests}

The authors have declared that no competing interests exist.

\section{Authors' contributions}

All authors contributed equally to this work.

\section{Ethical consideration}

The researchers were honest in the whole process of data collection and analysis, as well as objective in interpretation of the same data. They had respect for intellectual property, social responsibility and confidentiality. The research was above all non-discriminatory.

\section{Funding information}

The authors hereby admit that the research and the writing of this article were based on self-support.

\section{Data availability statement}

Data sharing is not applicable to this article as no new data were created or analysed in this study.

\section{Disclaimer}

The views and opinions expressed in this article are those of the authors and do not necessarily reflect the official policy or position of any affiliated agency of the authors.

\section{References}

Abutudu, M., 2010, 'Federalism, political restructuring and the lingering national question', in S. Adejumobi (ed.), Governance and politics in post-military Nigeria, 23-60. Palgrave Macmillan, New York.

Akinrefon, D., 2017, 1999 constitution is Nigeria's mistake, viewed 08 October 2018, from https://www.vanguardngr.com/2017/08/1999-constitution-nigeriasmistake-sagay/.

Arnold, J.L., n.d., Acts: The first dissension, viewed 06 October 2018, from http:// www.cleartheology.com/expo/01Acts/Acts\%2015.html.

Atofarati, A.A., 1992, The Nigerian civil war: Causes, strategies and lessons learnt, viewed 08 October 2018, from https://www.globalsecurity.org/military/library/ report/1992/AAA.htm

Ayeni, M.A. \& Adeleye, J.O., 2013, 'Education and political restructure in Nigeria', Journal of Education and Learning 2(1), 171-175. Canadian Center of Science and Education. https://doi.org/10.5539/jel.v2n1p171

Bello, S.A., 2017, Restructuring Nigeria: A critical analysis, viewed 08 October 2018 from https://www.thisdaylive.com/index.php/2017/06/11/restructuring-nigeriaa-critical-analysis/.

Berkhof, L., 2003, Systematic theology, Banner of Truth, Carlisle, PA.

Bullinger, E.W., 1898, Figures of speech used in the Bible, Messrs. Eyre \& Spottiswoode, London.

Chambers, A., 2012, Exemplary life: A theology of church life in acts, B\&H Publishing Group, Nashville, TN.

Chinweizu, I., 2006, Lugardism, UN Imperialism and the prospect of African power, in Dukuzumurenyi A. Chinweizu Articles, viewed 14 May 2019, from https://www. academia.edu/26905101/Collection_of_Articles_by_Professor_Chinweizu.

Constitution of the Federal Republic of Nigeria, 1999, viewed 30 October 2018, from https://publicofficialsfinancialdisclosure.worldbank.org/sites/fdl/files/assets/ law-library-files/Nigeria_Constitution_1999_en.pdf.

Curran, C.E., 1973, 'Politics, medicine and Christian ethics', in G. Ngbea (ed.), Religion, politics and national development. Nsukka Journal of Religion and Cultural Studies 5, 102-116. Nsuk
Nugeria, Nsukka.

Deyoung, C.P., Emerson, M.O., Yancey, G. \& Kim, K.C., 2003, United by faith: The multiracial congregation as an answer to the problem of race, Oxford University Press, New York, NY.

Douglas, L., 1971, 'The history of Jewish Christianity in the early Roman Empire (30-135 AD)', unpublished M.A thesis in Classics, viewed 14 May 2019, from http://digitool.library.mcgill.ca/thesisfile49165.pdf.

Dunn, J.G.D., 2009, 'Christianity in the making', vol. 2, Beginning from Jerusalem, Eerdmans, Grand Rapids, MI.

Editorial Board, 2016, 'Restructuring and its benefits for all', The Guardian, viewed 04 October 2018, from https://guardian.ng/opinion/restructuring-and-its-benefitsfor-all/.

Ellicott, C.J., 1897, A New Testament commentary for English readers, Cassell and Co., London, viewed 06 October 2018, from https://biblehub.com/commentaries/ Ellicott/acts/6-2.htm.

Fan, A.F., Jerry, J. \& Nnaraonye, O.G., 2014, 'Towards proffering a solution to the persistent religious intolerance which is a bane of development in Nigeria', Global Advanced Research Journal of Educational Research and Review 3(2), 22-27.

Gagnon, A.G., 1993, The political uses of federalism, Researchgate, Presses de L'Université Laval, Quebec.

Harnack, A., 1909, The Acts of the Apostles, G.P. Putnam, New York.

Joseph, Y., 2014, 'Federalism, National pluralism and ethno-religious conflicts in Nigeria: A normative interrogation of the peace-promoting and integrative function of federalism in Nigeria', An unpublished PhD Dissertation.

Karlson, H., 2009, Academic Theology, viewed 30 September 2018, from https://www. crisismagazine.com/2009/academic-theology.

Kinoshita, G., 2015, 'The book of acts as a case study: Examining the Ministry of Reconciliation', Justice, Spirituality, \& Education Journal 3(1), 76-77.

Kraybill, D., 2003, The upside-down kingdom, Herald Press, Scottdale, PN.

Linthicum, R., 2005, Building a people of power, Authentic Books, Colorado Springs, CO. 
Makinde, F. \& Dada, P., 2017, Nigeria won't progress with 1999 constitution says Bisiakande, viewed 06 October 2018, from https://punchng.com/nigeria-wontBisiakande, viewed 06 October 2018, from https:/
progress-with-1999-constitution-says-bisi-akande/.

Marguerat, D., 2002, 'The First Christian Historian: Writing the Acts of the Apostles', transl. K. McKinney, G.J. Laughery \& R. Bauckham (eds.), SNTSMS 121, Cambridge University Press, New York.

Mueller, J.T., 1934, Dogmatic Theology, Concordia Publishing House, St. Louis, MI.

Ngbea, G., 2012, 'Religion, politics and national development', Nsukka Journal of Religion and Cultural Studies 5, 102-116.

Ngele, O.K., 2008, 'Religion, politics and ethnicity: Challenges of pluralism in Nigerian development', Bassey Andah Journal 1, 177-190.

Nwafor, N.H.A., 2011, 'Social reconstruction: Implication for Nigerian education', Paper presented at 29th annual conference of PEAN held at Lagos State University.

Obidimma, A.E. \& Obidimma, E.O.C., 2015, 'Restructuring the Nigerian Federation for Proper Functioning of the Nigerian Federalism', Public Policy and Administration Research 5(9), 147-157.

Oguntola-Laguda, D., 2008, 'Religion and politics in a pluralistic society: The Nigerian experience', Politics and Religion II(2), 123-133.

Omotola, J.S., 2010, 'Political parties and the quest for political stability in Nigeria', Taiwan Journal of Democracy 6(2), 125-145.
Onyekpe, N.J.G. (ed.), 1998, 'Politics and political power in Nigeria: Mature, dynamics and determinants', in M. Dukor (ed.), Philosophy and politics: Discourse on values and power in Africa, Obaroh and Ogbiriaka publishers, Lagos.

Parsons, M.C., 2015, Reading Acts as a Sequel to the Fourfold Gospel, Institute for Faith and Learning at Baylor University, Waco, TX.

Pennock, J.R. \& Smith, D.G., 1964, Political Science: An introduction, Collier-Macmillan, London.

Slick, M., 2018, Acts 6:1-7 Building the church of disciples, viewed 27 October 2018, from https://carm.org/sermon-acts-6-1-7-building-church-disciples.

Soludo, C., 2018, The political economy of restructuring the Nigerian federation viewed 06 October 2018, from https://www.thecable.ng/political-economyrestructuring-nigerian-federation.

Strauch, A., n.d., What every Christian leader needs to know about Acts 6, viewed 06 October 2018, from https://lewisandroth.com/wp-content/uploads/acts-6-2018. pdf.

Thurston, B.B., n.d., The early church finds its way: Discernment in the Acts of the Apostles, re-printed from Hungryhearts, PC, USA, Office of Theology and Worship March 2011, Hungryhearts, Louisville, KY.

Tolan, J., 2015, 'Jews and Muslims in Christian law and history', in A. Silverstein \& G. Stroumsa (eds.), The Oxford handbook of Abrahamic religions 166-188. Oxford University Press, Oxford. 